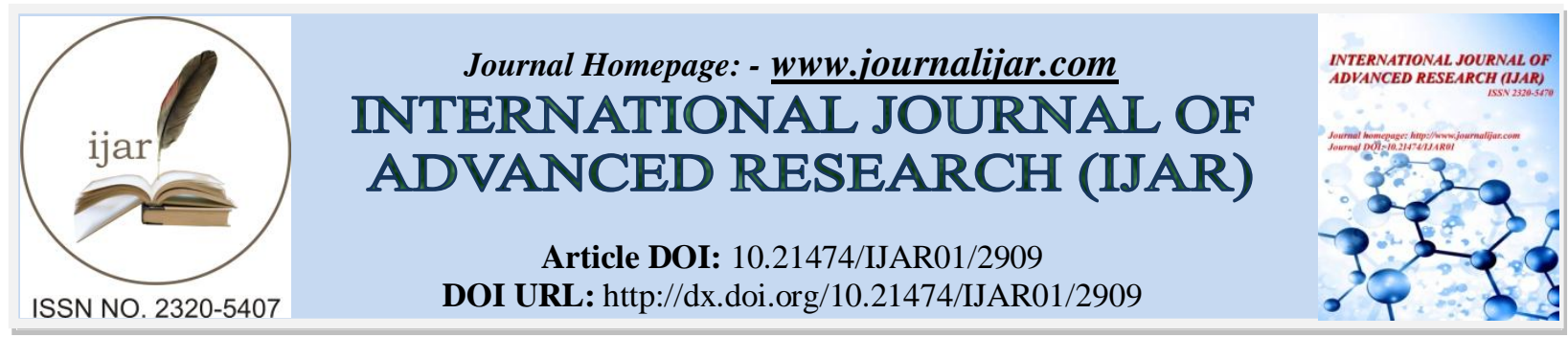

RESEARCH ARTICLE

\title{
IMPACT OF MAHATMA GANDHI NATIONAL RURAL EMPLOYMENT GUARANTEE SCHEME IN HARYANA.
}

Trilochan Chorasia ${ }^{1}$ and Mahesh Kumar ${ }^{2}$.

1. Research Scholor in Management, Punjab Technical University, Jalandhar punjab.

2. Assistant Professor, Delhi university, Delhi.

\section{Manuscript Info}

\section{Manuscript History}

Received: 24 November 2016

Final Accepted: 25 December 2016

Published: January 2017

Key words:-

Radiotherapy, Collagenase gene, cancer and Swiss mice.

\section{Abstract}

Estimates of the total number of unemployed or underemployed people in India vary between 50 to 300 million. The Economic Survey of India has reported that the unemployment rate increased from 5.99 per cent in 1993-4 to 7.32 per cent in 1999-2000. To make matters worse, young people accounted for 53 per cent of the total unemployed in the country.

In absence of viable and reliable social or economic security of any kind, the majority of Indians have no option but to slave under appalling conditions for less than decent wages, often from childhood to old age. The case of brick kiln workers and also the efforts made by Swamy Agnivesh to get bonded labourers freed are telling. The brick kiln workers are not allowed to leave the work, even when some of them have no debt.

In 18 out of the 32 states and union territories where legislation on minimum wages applies, the minimum permissible daily wage is less than Rs 50; the range of minimum wages rises above Rs. 100 only in four states. It goes without saying that even such low minimum wages are not always paid. To make matters worse, there are seasonal variations in availability of work and calamities of various kinds from drought to social conflict - adversely affecting employment and livelihoods on a regular basis.

A number of programmes have been initiated in the country to provide gainful employment, enhancing rural peoples' skills, their income and thus to ensure their food security etc. but without the tangible and expected results from each of these programmes

Under the pressure of social groups, the congress party made NREGA a part of its election manifesto. Later on strong stand by the NAC and pressure of left parties on whose support the govt. was formed, it was made an essential aspect of National Common Minimum Programme of the UPA - I. The NREGA was passed in 2005 and brought into implementation in Feb. 2006, initially in 200 most backward districts spread over 27 states, another 130 districts in the following year (113 from $1^{\text {st }}$ April and 17 districts of UP from $15^{\text {th }}$ May). The entire country was covered in the third year of its implementation, i.e., from $1^{\text {st }}$ April, 2008. 
The Act aims to provide on demand employment subject to 100 days minimum per household in a year to the rural poor through public works. It is expected to have the additional benefit of developing the infrastructure base in the countryside. Further, and importantly, an unemployment allowance has to be paid if work is not provided for any reason.

Copy Right, IJAR, 2016,. All rights reserved.

\section{Introduction:-}

The Mahendergarh district of Haryana was one of those in the first phase. In its village Satnali, one Mr. Mahesh Kumar, 28 years of age, became the first person in the entire country to get himself registered on February $2^{\text {nd }}$ to get 100 days employment @ Rs. 90/- a day. Now the wage rate under NREGA is Rs. 141 and minimum wage Rs. 151 in Haryana, which was revised on July 2009 from Rs 148 per day.

Along with Kumar, at around the same time, all 132 panchayats in the district held their special Gram Sabha meetings when work was a legal right. But in Haryana there had been labour shortage which was met by immigrant labour from states like Bihar on regular basis.

According to the information from the Department of Rural Development, Haryana fell short of the target in utilising funds as the number of applicants was insufficient.

The state could utilise only Rs 52.35 crore out of Rs 58.20 crore funds earmarked under NREGA in 2007-08.

Similarly, out of Rs 160.12 crore available, the amount spent under NREGA was Rs 110.00 crore in 2008-09. Thus only 70 per cent utilisation of the available funds could take place.

In the financial year 2007-08, 161,000 households were issued job cards which increased to 217,000 households in 2008-09.

The state has approved a labour budget of Rs 220 crore from the Union Ministry of Rural Development and this is for the first time that a labour budget has been sanctioned in advance, which is subject to revision, if required.

The Scope of NREGA has been enlarged which may help the state to fully absorb the funds which include land development, irrigation facilities and horticulture plantation which has been permitted to small and marginal farmers.

In Haryana, out of 1.5 million farmers, 998,000 (about $2 / 3^{\text {rd }}$ ) are small and marginal farmers. A number of reports have come out with unsatisfactory outcome of NREGA, particularly with regard to its implementation.

The present study based on Haryana experience attempts to look into the progress and achievements made in its implementation with the following specific objectives:

1. Identification of factors determining participation in NREGA

2. Impact of implementation of NREGA on employment generated, share of women in employment and change, if any, jn their social status due to self earnings

3. Impact on wage differentials, across activities and also on non- NREGA works

4. Impact of NREGA on rural- urban migration.

5. Impact of NREGA on assets creation and their sustainability

6. Impact of NREGA on rural food security, and,

7. Overall assessment and policy implications for further strengthening of the programme.

8.

For collection of data, five districts, Mewat, Ambala, Panipat, Sirsa and Rewari were selected. From each district two villages - one within a radius of $5 \mathrm{kms}$ and the other beyond $20 \mathrm{kms}$ were to be selected. From each village 25 
respondents -20 beneficiaries of NREGA and 5 non-beneficiaries were selected for detailed enquiry. Overall the study is based upon a sample size of 250 individual respondents and 10 villages represented by the respective sarpanches/ Panchayat secretaries/ village pardhans/ or village level workers of the state government.

\section{Functioning of NREGA:-}

We have used secondary data as available on the web site to analyse the functioning of NREGA in the state. The purpose was to have a broader picture of implementation of NREGA in the state. Data on the web site are given quite in detail covering households with socio-economic characteristics (scheduled castes, scheduled tribes and other backward castes as well as forward castes and women workers with regard to issuance of job cards, employment generation, work demanded and provided etc. We have used data for the latest three years, viz. 2008-09, 2009-10 and 2010-11.

The work on NREGA in the state was started with two districts, Sirsa and Mahendergarh in the beginning, followed by other two, Mewat and Ambala districts in 2007 and in the remaining 17 districts in the third year. District Palwal was created in 2009-10. The progress of issuing job cards is significant during the three years. The share of SC households in the issuance of job cards was more than 50\% during the three years, though it decreased from 55\% 2008-09 to nearly 50\% in the latest year. The percentage growth of households issued job cards in the state as a whole was around $54 \%$.

As far as generation of person days of work was concerned, there was almost $41 \%$ increase in women participation in 2010-11 over 2009-10 and 50\% increase in 2010-11 over 2008-09. Overall the share of women in generation of work days was more than $30 \%$ in the three years.

Among the districts, Mewat and Jind created more than $41 \%$ work for women in the year 2010-11, while in Karnal about $44 \%$ work was created for women. The state and some districts have achieved magnificent growth in employment generation for scheduled castes.

So far as completion of works was concerned, share of Rural Connectivity projects within the districts as well as in the state was almost $1 / 3^{\text {rd }}$ during the last three years and it was continuously increasing from $32 \%$ in $2008-09$ to about $42 \%$ in 2010-11. It was followed by Water Conservation and Rain Water Harvesting measures with more than $20 \%$ share during the three years. Other

important projects getting about $15-16 \%$ share in the state as well as in the selected districts were Drought Proofing, Micro Irrigation etc. However, Rajiv Gandhi Gram Seva Kendra is also in focus. The utility of such Kendras is being questioned by the officials, village leaders and even by the conscientious NREGA workers.

About $25 \%$ of the total amount was spent in district Sirsa alone followed by Mewat among the selected districts in 2008-09. Among the activities about Rs.

5.5 crores were spent on renovation of traditional water bodies. In the following year the amount spent on ongoing/ suspended works increased by about $42 \%$. However, in 2010-11, the amount spent increased by about $101 \%$ over 2008-09. Like 2008-09 district Sirsa topped the amount spent in the following two years as well, in 2009-10 by spending about $17 \%$ and in the year $2010-11$ by spending about $19 \%$ of the total amount spent in the state.

Rural Connectivity attracted maximum of the amount spent. It was more than $38 \%$ of the total amount spent in the state in the year 2009-10 and also in the year 2010-11. Water Conservation and Water Harvesting followed the Rural Connectivity, wherein about $16 \%$ of the total amount was spent.

In sum maximum amount has been spent on Land Development, Rural Connectivity and Water Harvesting related works and all of them will have long term economies for the communities associated with.

Social audit of the works, verification of muster rolls, and, gram panchayats' and gram sabhas' meetings are key to the functioning of NREGA.

Total number of muster rolls used in the year 2008-09 for the state as a whole was 25985 but $93.8 \%$ were verified during the year. Similarly in $2010-11$ about $98 \%$ muster rolls in the state were verified. However, among the 
districts selected for the sample, the muster rolls due and verified mostly match, except in Sirsa where only 67\% muster rolls were verified.

The situation related with verification/ completion of Panchayats was no better than verification of muster rolls. In the state as whole, during the year $2010-11$ about $40 \%$ verification of panchayats was not completed, whereas in the previous two years figure were about $29 \%$ and $40 \%$ less number than the total due.

In the state about $81 \%$ and $78 \%$ works were inspected. During the first two years, whereas in the year 2010-11 almost all the works are shown as inspected, though at district level we find many lagging.

In many districts of the state meetings of the gram sabhas were not held, which as per the act was mandatory. It was in the year 2010-11 that in two districts, Ambala and Sirsa all the gram sabhas met. The assignment of social auditing is yet to mature.

We find number of individual and joint bank and post office accounts of NREGA workers increasing during the three years. But still a huge portion of wages is paid in cash. Secondly, money disbursed as wages through bank and post office accounts as percentage of total amount spent on completed and ongoing projects during the three years, 2008-09, 2009-10 and 2010-11 was merely 13.7\%, 6.5\% and 15.9 Keeping in mind the level of misappropriation of public funds, the disbursal of innocent workers' wages in cash is neither recommended and nor desired.

No unemployment allowance was paid even it had been reported as due for some considerable days during the year 2009-10 and for a few days in 2010-11. As far as work projection is concerned, about 7.8 million work days for unskilled workers were projected to be generated which would mean that 78, 000 workers getting 100 days work during the year. A similar act for the urban poor will lift the entire state out of hunger and poverty and many more evils.

\section{Demographic profile of the respondents:-}

The average size of the households of the beneficiaries was noted significantly large (5.59) than those nonbeneficiaries (4.86) members per household. Also the earning members were more (2.68) in NREGA families than (2.36) in non- NREGA families. The ratio of male and female workers was about 55\% and $45 \%$ under the NREGA category as compared to 56 and $44 \%$ under non- NREGA category. Also in the beneficiary households percentage of females was higher, 832 per 1000 males as compared to 783 in non-beneficiary households. In the working age groups of less than 60 more percentage of workers is found under beneficiary category as compared to nonbeneficiaries. Whereas in the age group of more than 60 years, which is not considered suitable for physical labour a negative indicator, more people above 60 work under non-NREGA activities. Looking at the education level of both beneficiaries and non-beneficiaries, we find more percentage of people educated at primary level in the case of beneficiary households. But in the case of illiterate persons, the major difference of about $5 \%$ exists as more people are illiterate in the case of beneficiary households.

As far as card holding pattern is concerned, we did not find any worker holding AAY card holder availing benefits under NREGA. Workers below poverty line were more than $80 \%$ in aggregate and $80 \%$ in the case of beneficiaries.

As far as migration is concerned, a very small number of persons (only 2 out of 1356) migrated during the reference year 2009.

The percentage of total man days per household as main profession was highest under agricultural casual work for the beneficiaries and non- agricultural casual work for the non-beneficiary category. But non- agricultural casual work provides significant work for the beneficiary households also. Nonetheless for $25 \%$ beneficiary households work under NREGA was main profession. Moreover, the extra employment generated through NREGA would create extra income pushing up demand for other items like fruit and vegetables, resulting in more employment and income to the venders and growers with forward and backward linkages.

For the NREGA beneficiaries, about $25 \%$ per household income also was received from NREGA activities, about $37 \%$ from agricultural labour, 33\% from working on other than agricultural operations, and about $4 \%$ income came from livestock. In the case of non-beneficiary sample households, the largest share of household income (60\%) 
came from non-agricultural wages, followed by (34\%) wages received by doing casual agricultural work and about $5 \%$ income was generated by rearing livestock.

Across households the variation in income has been measured by Coefficient of variation. The CV in this case was the highest for beneficiaries, followed by income from agricultural wages. However, in the case of non-beneficiary households the highest variation was found in the case of income from agricultural wages then followed by nonagricultural wages.

As far as per capita monthly consumption of different edible items between beneficiaries and non-beneficiaries was concerned, no significant pattern emerged, except that overall food consumption was in favour of the beneficiaries. However, in terms of total monthly per capita consumption expenditure many important issues get highlighted. For example, monthly per capita consumption expenditure on food items works out to Rs, 487/- This small expenditure in both the cases of beneficiaries as well as non- beneficiaries may not be enough to save poor workers suffering from malnutrition, if not from hunger without NREGA. Even NREGA alone in the present form of providing 100 days' work at a fixed wage, will not address the issues of providing sufficient food, if the food was not provided at subsidized rates, mostly through the PDS. Because, per day per capita consumption expenditure of Rs. 13 per day in the case of beneficiaries and Rs. 12.4 in the case of non-beneficiaries, was not sufficient to provide two times food to satisfy one's hunger. Though NREGA seems to have benefited the poor directly by delivering some money and indirectly to non-beneficiaries by increasing overall wage rates, particularly during peak season, but to alleviate poverty and hunger some other steps need to be taken or improved. Wage rates need to be inflation neutral. Without effective PDS nothing will be effectively helpful to the poor to meet both ends. Many more items (food as well as non- food) need to be put under the PDS to increase their real income. Coming to the issues of beneficiaries vis-à-vis non-beneficiaries, overall persons benefiting from NREGA seem to be slightly better off, which further strengthens the arguments favouring NREGA.

In sum one can say that though progress of NREGA seems to be somewhat below targets to address the issues of gender equality with regard to employment generation and income, social equality by creating more opportunities for the deprived sections, it has helped in improvement of provision of food in the state, particularly in sections dependent mostly on wage labour.

\section{Work profile under NREGA:-}

As far as the work profile of the NREGA workers was concerned, the number of workers per household finding work under NREGA activities, varied from 1.35 to 1.98 in the selected districts. The average for the state as whole was 1.72 persons per household. Different social groups wise in the state as a whole, 1.75 members per household from the general category, 1.66 from scheduled Caste households, 2.33 from scheduled tribe households and 1.74 from the OBC households were getting work during the period. The number of females per household 0.62 working under NREGA activities was the lowest. Thus probably the targeted deprived sections like scheduled castes were the largest group of people to find per household work for number of family members under NREGA but the other deprived section the women, was the smallest.

The inter district variation observed in per household number of people finding work under NREGA was in the range of 1.98 in Mewat to 1.35 in Panipat. In other words, the most deserving region was able to generate more work for members per household. If the females could also be involved in a little more aggressive way, the objective of NREGA as far as involvement of different social and targeted groups and regional consideration was concerned, could have been largely met.

During the period under reference in aggregate 80 (exact 79.7) to 110 (109.5) days' work per household in the selected districts was provided, in two districts, Sirsa and Mewat, even exceeding the annual target of minimum 100 days work. In the state as a whole more than 94 days' work per household was provided during the period. Among different social groups ST households in districts Sirsa and Mewat were the largest beneficiaries getting more than 160 days' work per household during the period. In district Sirsa general category households got maximum work of 160 days. Overall in the state women got about 30 days' work per household in the state during the period.

However, per member work provided during the period varies drastically inter districts as well as inter social groups. In aggregate inter district variation is recorded from 44days (lowest) in district Rewari to 62 days in district 
Ambala.

Similarly among the SC members lowest number of days was 29.34 in district Sirsa to highest being 112 days in district Mewat. The lowest variation among all the groups is found in OBC members, varying from 47.47 per member in district Ambala to 58 the highest variation in district Sirsa. Among the women, the variation was found between 37 days to about 52 days.

As far as wage rate was concerned, during the period the average wage rate was about Rs 150 per day, varying across sections marginally, among ST and women workers for example. The ST workers received lowest wages (Rs. 147) among all. Though the difference in minimum prescribed (Rs. 148) at that time and the lowest paid (Rs. 147) was marginal but considering the prevalent higher rate of wages in the state at that time, it was not that small too.

The average distance of work place from the residence in the state was about $2.23 \mathrm{Kms}$, varying from $1.28 \mathrm{kms}$. in district Ambala to $2.7 \mathrm{kms}$ in district Rewari. In the state between January and December 2009 (reference period) about $6 \%$ households were employed to work on rural connectivity projects. In two districts, Ambala and Panipat, there was no work on this activity whereas in the remaining three, percentage of households employed varied between 12.5 (Mewat) the maximum to 5\% the minimum in Rewari. Surprisingly In none of the selected districts work on water conservation was being undertaken.

As far as quality of these works was concerned, maximum respondents, 79\%, reported it to be very good, and about $20 \%$ reported it to be of good quality. None of the respondents stated it of bad quality, and that is very significant response.

As providing employment allowance in lieu of work is state's responsibility, without any bearing on the central government, in the entire state efforts were made to see that not a single paisa is provided for allowance, and work to avoid stress on the state's resources is created as per demand. The introduction of more activities, such as developing horticulture, plantation, etc. will further reduce the pressure of finding and providing work to the needy in the village. If need be some categories of works presently covered under Khadi and village industries be considered for inclusion in NREGA. That will help provide work at door steps and open up more opportunities for the village panchayats to create jobs and productive assets.

The sample data show that there were negligible cases of immigration during the period.

\section{Household assets holdings:-}

The assets holding pattern of the respondents confirms that barring district Rewari, they were benefiting directly for the last two - three years in the state in the form of assured employment and extra income during the lean period. Barring utensils and other unspecified small items per household all major assets like land, house property, livestock, even a few ornaments of very little value were more valued in the case of beneficiary households vis-à-vis non-beneficiary households. The difference seems significant in the total value of assets. Aggregate value of all assets per household was Rs. 89 thousand and Rs.68 thousand respectively in the case of beneficiaries and non-beneficiaries. The major difference came from land and house property. Taking the value of beneficiary assets equal to one, we find that land in the case of non-beneficiary households is just 0.63 , house property 0.88 , live stock 0.91 , ornaments 0.64 and some other assets 0.92 . However, value of consumer assets was found slightly more than one, i.e. 1.18, and utensils 1.15 in the case of non-beneficiary households.

In fact, along with contribution in the creation of infrastructure like, water harvesting, land development, plantation, etc. contribution in enhancement of personal assets of the NREGA workers is important and NREGA seems to succeed in that area. Compared with Keynesian magical formula of digging the pits and then refilling them for the sake of creating jobs to lift the economy from depression, NREGA seems to be more effective way of doing many things simultaneously - removing poverty, ensuring food and nutrition for the most targeted sections, enhancing gender equality, productively utilizing the unused valuable human labour, creating infrastructure to be useful for future longer period, saving the society from turning chaotic or criminal, and most importantly, creating demand for the industry.

As far as financial position of the respondents was concerned, barring a solitary case of a loan of Rs. 50,000/- @ 
$13 \%$ interest from the SBI for establishing a shop by one beneficiary household, not a single case was reported by any other household, neither by beneficiaries nor by non-beneficiaries households because for getting a loan one has to provide some assets as collateral, which for the households dependent on wage labour if not impossible would be difficult to provide. To begin with, there seems a very positive impact of NREGA that people have begin to create productive assets even by taking loan, which otherwise could not be envisaged.

But the households both beneficiaries as well as non- beneficiaries did borrow from the private money lenders. The amount and terms of loan might not have been revealed by the respondents. The other information gathered from the respondents does provide an indication of the strict terms of loan from private sources. For example, $22 \%$ respondents in aggregate (23\% beneficiary households and $18 \%$ non-beneficiary households) did work for the lenders, they were indebted to.

Even though $18 \%$ reported that cooperative credit society was in existence in the village, $5 \%$ and $10 \%$ households respectively from beneficiary and non- beneficiary households were members of such a society, additionally, for the $12 \%$ respondents facility from formal credit society or Self Help Group was also available, about $7 \%$ family members were holding the membership of such a society or SHG. As much as $51 \%$ were also having live accounts in bank branch or post office, still no formal substantial credit line was opened to them.

Not only providing some material asset for collateral is essential to get loan from private sources, but also terms of repayment of loan in such cases are harsher ones, for example, high rate of interest, large repayment installments for fast recovery and some other conditions, like retention of some amount (may be one installment) even before making payment etc. That is what $23 \%$ beneficiary households and $18 \%$ non- beneficiary households reported doing wage labour for the lender.

As per the Act and rules the payment of wages to the NREGA workers has to be made either through the bank or through the post office. But only 53\% beneficiaries and 44\% non- beneficiaries reported having bank or post office accounts. Here also large percentage of bank accounts of beneficiaries is positive impact of NREGA. But only $78 \%$ respondents got the wages transferred to their bank accounts and 13\% were paid by the sarpanch, In $21 \%$ cases of delayed payment and in $8 \%$ cases of less payment of wages complaints were lodged while $65 \%$ did not lodge any complaint.

Worksite facilities like child care, medical care or even first aid, except drinking water were not in existence. A few things, need to be considered seriously: One, to ensure economic welfare of these groups, along with implementing the provisions of the act seriously, credit facility with convenient terms and easy availability has to be provided, two, to protect their health some strong medical/ health arrangement, through strengthening public health care system, medical insurance cover, etc. need to be put in place so that these groups if come above poverty line do not fall back due to any such reason. Recent arrangement made for bidi workers can be extended through the National Rural Health Mission to bpl card holders at least, NREGA workers and other targeted groups. To maintain quality of assets and to ensure that no genuine worker is left uncovered under NREGA, monitoring through regular meetings of the Gram Sabha and of the monitoring committee has to be made effective. In a good number of cases there was no monitoring at all. But still the assets created were rated very highly, either very good or in some cases of good quality and expected to last for 5 years.

Food expenses for the poor always remain main head of expenditure. In poor households, particularly AAY and BPL card holders many times meals for two times for the entire family is not secure. To mitigate such distressing situation it is expected that under NREGA, along with other income from non-NREGA work or from resources like live stock etc, if one has, one will secure at least two times meals for the family, and none would go to bed with empty stomach. Moreover, to ensure that, the minimum work days under NREGA can be increased to let us say to 200 per hh or 100 days per job seeker in the beginning. In Haryana, though people below poverty line as well as without any tangible resources do exist, but because state govt. has been providing social benefits, like old age pension, benefits to girl child for education, marriage etc. food for school children, some medical relief for the poor, the situation that people will go without food, is rare. But that does not mean that these measures will not be needed.

The NREGA has also successfully made the people more aware and conscious about the schemes, though they may not be very well versed with all the technical aspects of NREGA. 
The NREGA through assets and infrastructure creation thus has generated great potential for the most deprived sections of the society, the poor, socially depressed classes and the women, who get employment and income during the lean period when it is most needed and thus helped them secure their food at least two times a day.

\section{Impact of NREGA on village economy:-}

The information gathered through village schedules shows that $90 \%$ villages were connected with roads. In $50 \%$ villages there were double roads connecting the villages to different cities/ towns on different routes. It was only in one village that the nearest road was $2 \mathrm{kms}$ away. No village was connected with railway station. The rail station on an average was $21 \mathrm{kms}$ away. Telephone connectivity was 100\%. In some villages even paid phone booths were noted. Post office facility was available only in $60 \%$ villages and the cooperative credit society in $40 \%$. Despite the clear cut policy of the RBI that a bank branch with population of more than 2000 has to be opened, there was no bank branch, RRB, Cooperative Bank, or scheduled commercial one, neither public sector and nor private. In fact, the situation of rural banking is the poorest one.

Self help groups were working in $70 \%$ villages, primary school was working in all the villages, secondary school in $80 \%$ and senior secondary in 50\%, PHC in $60 \%$, dispensary and fair price shop in $40 \%$ each. The problem is related with distance also. On average the fair price shop was distanced at about $14 \mathrm{kms}$. The gram pnachayat office was in all the villages.

The main concern of the nation now seems to be food security by providing nearly $70 \%$ people with subsidized food. In absence of fair price shops in $60 \%$ villages the task would be very difficult if not impossible. Therefore, urgent and effective steps would be needed.

Other infrastructure facilities like veterinary hospital/ dispensary, village purchase centre, mechanical workshop etc. did not exist in half of the sample villages. Village purchase centres have been a major successful story of the state, which helped not only the farmers to sell their produce at the nearest place, but many times at minimum support prices also. Additionally they have been a source of non-farm employment generation through linkages as well.

Historically with the development process, the people world over have been shifting away from agriculture. The percentage of cultivator households increased from $64.5 \%$ in 2001 to $65.2 \%$ in 2009 . The percentage of agricultural labourers decreased from $33 \%$ to $30 \%$ in the respective years. Those involved in trade and commerce activities increased from $0.5 \%$ to $1.3 \%$. The number of households doing other activities like working in household small industry, construction activities, transport and the like increased marginally from $2.1 \%$ in 2001 to $2.7 \%$ in 2009.

The number of cultivator households increased due to subdivision of households and holdings. The percentage of agricultural workers decreased due to availability of other less tiring and more rewarding works like small shops, trade etc. Overall, the development and nature of works do not suggest anything contradictory to the historical development process. Except that the rate of decrease of population dependent upon agriculture is much slower as compared to rate of decease of share of agriculture in the GDP.

In Haryana higher wage rates have been the great attraction for immigrant workers from Bihar, eastern UP and Orissa.. Even the immigrant workers were not enough to reduce the prevailing wage rates. Introduction of NREGA has further increased the wage rates, probably due to, one - that number of immigrant labour has come down, though not eliminated completely, and two - because due to lean season earnings from NREGA local workers are not that much hard pressed to work under distress conditions. The increase in all type of wages both for male and female workers, during the period under reference has been noticed all around. In the wages of male workers almost $30 \%$ increase in agricultural wages, $40 \%$ increase in non-agricultural wages, $36 \%$ rise in wages for construction work, more than 50\% increase in mining, between $28 \%$ and $48 \%$ increase in the wages of semi skilled workers like electrician, plumber, pump set operators and mechanics has been noticed. Similarly in the case of female workers, almost $44 \%$ increase in wages for agricultural work, more than $49 \%$ for non-agricultural work, about $43 \%$ increase for construction work and 50\% increase in the case of mining has been noticed. Along with effect of NREGA, general increase in price index and relatively more profits and more demand for work in construction and mining etc. due to overall increased growth rate of the economy and increase in value of 
agricultural output due both to prices and production, can be the possible reasons.

Overall the average wage rate after NREGA has gone up handsomely.

It is pointed out by many studies/ reports. The latest being report by the Secretary Rural Development that NREGA has affected the wage rates positively by 2 to 2.5 times as compared to pre NREGA situation.

The labour charges per day for different agricultural operations have gone up two to three times in comparison to pre NREGA period. With so many changes all around, it is but essential that village economy, particularly cost of production, consumption pattern, migration and immigration etc, get affected. Shortage of agricultural wage labour at some point of time was reported by $70 \%$. Even shortage of agricultural labour was expressed by $40 \%$. Enhancement in cost of production by $20 \%$ to $50 \%$ was told by $10 \%$.

Surprisingly and rightly too all the people agreed that there was no change after NREGA in the position of attached labourers, and probably it is the serious and negative aspect of NREGA. Because increase in wage affects them directly when they have to pay for the hired labourer by the land owner when they (attached workers) absent from work.

Finally on the question of improvement in NREGA two interesting suggestions were put forward - one more money, i.e., enhancement in wages and its immediate payment, and two, work for more than 100 days and not restricted to one member per household. Its scope needs to be enlarged to cover every one willing to work for as many days as one wants to work.

\section{Concluding Remarks:-}

From the above discussion and the relevant data, two issues come up clearly - one directly related with NREGA its positive aspects and shortcomings in its implementation, and two, issues related with other aspects where NREGA and other schemes intermingle. it can be concluded that NREGA has helped improve the income level of the beneficiaries, through both, increase in wage rates and enhancement in their bargaining power, their food security, and that too with productively utilizing the scarce resources. The targeted groups, scheduled castes, scheduled tribes and women (to some extent) are the main beneficiaries of NREGA. The assets created are worth the money. The increase in percentage of school going children should be the major gain of NREGA combined with other measures like mid day meal, scholarship, free uniform, books etc. The position of attached workers who have not come out of the clutches of the rural rich is revealing.

However, many more things need to be done to improve the situation of rural India, for example, strict monitoring through Gram sabhas of the projects, list of beneficiaries, muster rolls, job cards, payment etc. In fact, the sarpanch centric system of panchayti raj needs to be made gram sabha centric through devolution of more democratic powers to the people. However, we would like to emphasize a few things for policy consideration:

1. Expansion of NREGA (200 days work per hh or 100 days work per job card) should be the minimum.

2. For improvement in the implementation, toll free application registration, complaint registration call centre scheme be made compulsory.

3. For accounts in banks, payments, job cards etc related issues administrative camps (like administration to the villages in Rajasthan, where all the officers camp in the village on specified day to settle all the issues) should be started.

4. Flow of Funds needs to be regular and not at the end of the year. For proper maintenance of records trained staff should be need based and recruited in a more liberal way instead of the present system of one project officer and one accounts assistant.

5. For monitoring of work, selection of work etc. involvement of workers' association along with some independent committee of village educated persons, may be teachers and retired government officials residing in the village, senior officers of the district, and academic staff of the local college etc. may be involved.

6. However, some other measures related with overall situation, other institutions also should be considered.

7. Credit facility through financial institutions needs to be improved to lift the poor above the poverty for longer periods.

8. For enhancement in real income through strengthening the PDS by inclusion of more edible as well as nonedible items at reasonable rates like CSD for the armed forces may be considered. 
9. Immediate and effective steps for the welfare of the attached labour need to be taken.

10. More effective steps to strengthen the economy of the most backward sections of the society like artisans who have lost their traditional work under the new policies and development process like lohars, kumhars, carpenters, etc. need to be taken up on priority basis.

11. Health care of the rural poor needs to be taken care of either through the more effective way of public sector health services (NRHM) or through the insurance coverage.

12. For all these and many more welfare activities, the already going on schemes, like RKVY, Khadi and Village Industries, Sarve Shiksha Abhiyan.

13. Mother- Child care etc. need to be integrated and converged. Broad policy framework under the total monitoring of the Gram Sabha and grass root associations of the poor should be considered. The integration of schemes will help reduce the duplicity of works and projects.

14. Funds available under MPLAD, RKVY, RD and from other state and centre govt. departments should be pooled and used on the lines of RKVY and for that a greater coordination among centre and state governments, different ministries and departments need to be explored.

\section{References:-}

1. Sinha, B.K Secretary (R.D), T. Vijay Kumar, JS(SGSY) and N.K. Sinha, JD(NREGA): Tour Report on the visit of Sirsa (Haryana)

2. P. Sainath: Hindu (various write ups) Roy and N.Day: CATALYST Vol. VII. Issue 2, 19 Engel, Ernst [1857], 2nd ed. pp. 28-29

3. SHAILLY KEDIA: Development Studies Association (DSA) Annual Conference, September 2009 Vidhya Das: NREGA - Orissa Experience, ceva

4. Dr'eze and Sen 1991, Dev 1995 "Strategies of Entitlement Protection". In Hunger and Public Action, pp. 104 121

5. India Centre for Research in Rural and Industrial Development, (CRRID): Appraisal of impact assessment of NREGS in selected districts of Himachal Pradesh, Punjab, Haryana. Districts Hoshiarpur, Sirsa and Sirmaur, July-August, 2009

6. Prime Minister, Dr. Manmohan Singh: various speeches, address to the nation Drèze and Sen: Hunger and public action, oxford, 1989

7. Reetika Khera Economic \& Political Weekly, August 30, 2008 Jean Drèze and Christian Oldiges: How NREGA is doing?

8. Sapna kedia: Sustainable Development through Inter-sectoral Convergence IFPRI discussion Paper 00963, 2010

9. ET Bureau, 26.3.2010

10. Aruna Roy and N Day: NREGA: Breaking new ground, The Hindu Komal Gera, Business Standard, New Delhi, Sep.22, 2009

11. Sonu Jain: Indian Express, Feb 03, 2006 Economic Survey 2009-10

12. Joseph. Is the media watching poverty enough, India Together, Times of India, Oct. 28, 2005

Prof. CHH Hanumantha Rao and Dr. P. Rangaswamy: evaluation of IRDP, Planning Commission, Govt. of India. 